\title{
Genişletilmiş Alternatif Bir Kompulsif Satın Alma Davranışı Ölçme Aracı Önerisi
}

\author{
An Extended Alternative Compulsive Buying Behavior Assessment Tool Proposal
}

\author{
Alişan BALTACI ${ }^{1}$, Zeliha ESER ${ }^{2}$ \\ 'Yüksek İhtisas Üniversitesi Sağlık Hizmetleri Meslek Yüksekokulu, Tıbbi Hizmetler ve Teknikler Bölümü, Ankara, Türkiye \\ ${ }^{2}$ Başkent Üniversitesi İktisadi ve İdari Bilimler Fakültesi, İşletme Bölümü, Ankara, Türkiye
}

öz

$\mathrm{Bu}$ araştırmada amaçlanan, kompulsif satın alma davranışı ile ilgili olarak yazında en sık kullanılan iki ölçeğin birleştirilmesiyle kavrama dair daha geniş tabanlı bir ölçme aracı geliştirmektir. İki ölçeğin maddeleri birleştirilerek oluşturulan soru formu 776 kişiye uygulandıktan sonra güvenilirlik testine ve faktör analizine tabi tutulmuştur. Faktör analizi ile elde edilen beş boyutlu yapı doğrulayıcı faktör analizine tabi tutulmuş ve nihayetinde 25 soru, 5 boyuttan oluşan, yüksek güvenilirlik değerine sahip genişletilmiş bir ölçme aracı elde edilmiştir.

Anahtar Sözcükler: Kompulsif satın alma davranışı, ölçek, yapısal eşitlik modellemesi, tüketici davranışı
ABSTRACT

This research aims to combine the two primarily used scales to measure compulsive buying behavior to achieve a broader-based measuring instrument. After applying the combined scale on 776 attendants, a reliability test and factor analysis have been conducted on the collected data. Five dimensions have been obtained by the factor analysis, and this structure has been tested by confirmatory factor analysis. Finally, the extended measuring instrument has been constituted, with 25 questions, five dimensions, and a high-reliability score of Cronbach's Alpha.

Keywords: Compulsive buying behavior, scale, consumer behavior, structural equation modeling

Cite this article as: Baltacı A, Eser Z. Genişletilmiş Alternatif Bir Kompulsif Satın Alma Davranışı Ölçme Aracı Önerisi. YIU Saglik Bil Derg 2021;2:39-48.

\section{Giriş}

Kompulsif satın alma davranışı (KSAD), bir duygu durum bozukluğu olup; bireyin yaşadığı olumsuz ve mutsuz edici tecrübeler neticesinde ortaya çıkan, engellenemez ve kronik bir satın alma davranışı olarak tanımlanabilir (1-6). Zaman içerisinde bireyin önce maddi, ardından manevi kaynaklarını yitirmesine sebep olabileceğinden tehlikeli bir davranış bozukluğu olduğunu ifade etmek yerinde olacaktır. Dolayısıyla pazarlama literatüründe genel kabul gören seçim, beklenti, eylem ve benzeri teorilerde sıklıkla vurgulanan fayda maksimizasyonu yaklaşımının aksine bir davranış biçimidir. Kompulsif satın alma davranışı tüketicilerin karar alma sürecinde rasyonel davranış göstermediğinin farkına varılması sonucu literatüre girmiş olup bu konuda çeşitli ölçekler kullanılarak çalışmalar yapılmıştır (Örn.: 6-10).

Yapılan literatür taramasında en sik başvurulan ölçeklerin Faber ve Q'Guinn (8) ile Edwards'ın (9) geliştirmiş oldukları tarafımızca tespit edilmiştir. Bu iki ölçek mukayese edildiğindeyse Faber ve O'Guinn (8) ölçeğinin daha sık kullanıldığını söylemek mümkündür. Aslında ölçekler arasındaki farklılığı araştırmacıların kompulsif satın alma davranışı tanımlarından yola çıkarak anlamak da mümkündür. Faber ve O'Guinn (8), kompulsif satın alma davranışını "bir nesneye veya tecrübeye sahip olmak ile ilgili kontrol edilemeyen bir duygu veya arzuya defalarca kez yenik düşme ve bu durum ile kendisine ve etrafindakilere zarar vermek" olarak tanımlamışlardır. Edwards (9) ise "dertli/sorunlu bireyin olumsuz duygulardan, kaygılardan ve stresten uzaklaşmak için kontrolsüzce, kronik olarak ve tekrarlayacak şekilde alışveriş ve harcama yapmak sureti ile bu olumsuz ruh halinden kurtulma veya hafifletme eylemi" olarak tanımlamıştır. Bu iki tanım da aynı kavramı tanımlamak için yapılmış olmakla beraber birincisi bir ürüne sahip olmak için bireyin hissettiği mecburiyeti, ikincisi ise bu davranışın olumsuz bir takım duygular sebebiyle ortaya 
Tablo 1. KSAD dair öne çıkan tanımlar

\begin{tabular}{|c|c|c|}
\hline Yazar & Yll & Tanım \\
\hline Faber vd. & 1989 & Bireyi uygunsuz bir şekilde satın almaya yönlendiren yıkıcı bir dürtüdür. \\
\hline McElroy vd. & 1994 & Kontrol edilemeyen, üzücü, zaman tüketen bir davranış olup maddi sorunlara sebep olmaktadır. \\
\hline $\begin{array}{l}\text { Dittmar } \\
\text { ve Drury }\end{array}$ & 2000 & $\begin{array}{l}\text { Sapkın bir davranış olup normal tüketici davranışından nitelik olarak farklıdır ve normal davranış modelleri bu tip satın } \\
\text { alma dürtüsünü açıklayamamaktadır. }\end{array}$ \\
\hline $\begin{array}{l}\text { Miltenberger } \\
\text { vd. }\end{array}$ & 2003 & Olumsuz duygu ve olaylara bir tepki olarak ortaya çıkar ve bunların hassasiyetini azaltır. \\
\hline Dittmar & 2004 & $\begin{array}{l}\text { Satın alma dürtüsü; bireyin satın alma davranışı üzerindeki gücünü kaybetmesi sonucunda sosyal ve mesleki hayatını ret } \\
\text { edilemez bir şekilde göz ardı ederek gösterdiği ve sonunda maddi sorunlar yaşamasına sebep olan bir davranıştır. }\end{array}$ \\
\hline Jalees & 2007 & $\begin{array}{l}\text { Hayati bir fonksiyonu ölümcül bir şekilde etkileyen, kişinin kendini kaybetmesiyle ortaya çıkan bir satın alma } \\
\text { bağımlılığıdır. }\end{array}$ \\
\hline Mittal vd. & 2008 & Bireyin ihtiyaçları dışında olmasına rağmen bazı ürünleri satın almak konusunda gösterdiği kronik eğilimdir. \\
\hline Ridgway vd. & 2008 & $\begin{array}{l}\text { Dürtü eksikliği sebebiyle satın alma davranışı üzerinde kontrolünü kaybeden bireyin tekrar eden satın alma davranışı } \\
\text { göstermesi durumudur. }\end{array}$ \\
\hline Billieux vd. & 2008 & Bireyin ailevi ve kişisel olarak sorun yaşamasına sebep olan, kontrol edilemeyen abartılı bir satın alma davranışıdır. \\
\hline
\end{tabular}

çıktığını vurgulamaktadır. Bu çalışmada aynı kavram için yapılan bu iki tanımın çıktıları olan ölçekleri birleştirmek sureti ile bu tanımları bir araya getirmek ve kavramın daha geniş bir çerçevesini çizmek hedeflenmiştir.

\section{Kompulsif Satın Alma Davranışı (KSAD)}

Kompulsif satın alma davranışı (KSAD), bilim dünyasının gündemine psikoloji literatüründeki çalışmalarla girmiştir. Tamam vd. göre, “ilk olarak 1900'lü yılların başında satın alma manisi yada oniomani adı ile ortaya konulmuştur" (11). Çalışmalarda sıklıkla yapılan tanıma göre "olumsuz durumlar veya duygular neticesinde ortaya çılkan kronik, tekrar eden satın alma davranışı" olarak ifade edilmektedir (1). Edwards 1993 yılındaki çalışmasında kompulsif satın alma davranışını tanımlarken "bağımlılık yaratan bir süreç ve deneyim" demiştir (9). Literatürde bu davranış biçimini tanımlamak üzere "kompulsif alışveriş, satın alma manisi, kompulsif tüketim, dürtüsel satın alma, kontrol edilemeyen satın alma, dürtüsel satın alma, zorlayıcı satın alma vb." (11) gibi farklı tanımlar bulunmakla beraber literatürde en sık olarak "kompulsif satın alma davranışı” kavramının kullanıldığı görülmektedir. $\mathrm{Bu}$ sebeple çalışmada da kavram bu şekilde kullanılmıştır.

Deserabo ve Edwards kompulsif satın alma davranışı (KSAD) ile ilgili olarak yaptıkları tanımda "Kompulsif satın alma davranışı da diğer olumsuz davranışlar gibi dürtü kontrol eksikliği, depresyon, düşük benlik saygısl, onaylanma araylşı, anksiyete, materyalizm, dışlanma, mükemmeliyetçilik, eğlence arayışı ve olumsuz tecrübelerin inkârının bir sonucudur" demektedirler (12).

KSAD, bireyin toplumdan soyutlanabilmesine de sebep olabileceğinden dolayı oldukça önemlidir. Yapılan araştırmalarda bu eğilime sahip bireylerin sadece kendi hayatlarını değil, aynı zamanda ailelerinin de hayatlarını zora soktukları; çünkü sahip oldukları paradan fazlasını kontrolsüzce harcadıkları anlaşılmaktadır.

Günümüzde gelişen internet teknolojileri ile birlikte bu tip davranışın sanal mecralarda da gösterilebileceği ifade edilmektedir (13).

Tablo 1'de yıllar içerisinde KSAD ile ilgili öne çıkan çalışmalarda konu ile ilgili verilmiş olan tanımlar görülmektedir.

Tabloda verilen tanımlamaların arasındaki bir takım farklı ifadelere rağmen genel olarak iki ana temel üzerinde kesiştiğini söylemek mümkündür. Bunlar;

- Bireyin satın alma davranışı üzerinde kontrolünü yitirmesi,

- Bireyin davranışı sergiledikten sonra maddi ve manevi olarak hayatının olumsuz etkilenmesi.

Yapılmış geçmiş çalışmalardan yola çıarak kompulsif satın alma davranışının genel çerçevesi Şekil 1'de verilmiştir. Buna göre kompulsif satın alma davranışı; olumsuz duygu durumları (depresyon, stres, kayg1 bozukluğu vb.) neticesinde bireyin satın alma davranıșı üzerinde kontrolünü kaybetmesi üzerine yanlış bir satın alma kararı vermesi ve bu esnada geçici bir iyi hissetme hali yaşaması, akabinde yaptığı yanlışı fark ederek pişman olması, bu yanlışların sonuçta maddi-manevi tükenmeye sebep olması, ailevi-sosyal ilişkilerin bozulması ve sonunda bireyi tekrar olumsuz duygu durumları yaşaması ile davranışın yeniden bir döngü şeklinde tekrar etmesi söz konusudur. Kimler daha sık kompulsif satın alma davranışı gösterir sorusunun cevabı ise Şekil 1'in alt tarafında belirtildiği üzere; kadınlar, gençler, hayalperest kişiler, materyalistik eğilimi yüksek kişiler ve düşük sosyal statüdeki bireyler bu davranışı daha sık gösterir denilebilir. Ayrıca bu kitle nüfusun \%10'una tekabül etmektedir ve ayda ortalama 17-18 kompulsif satın alma atağ 1 geçirmektedirler. 


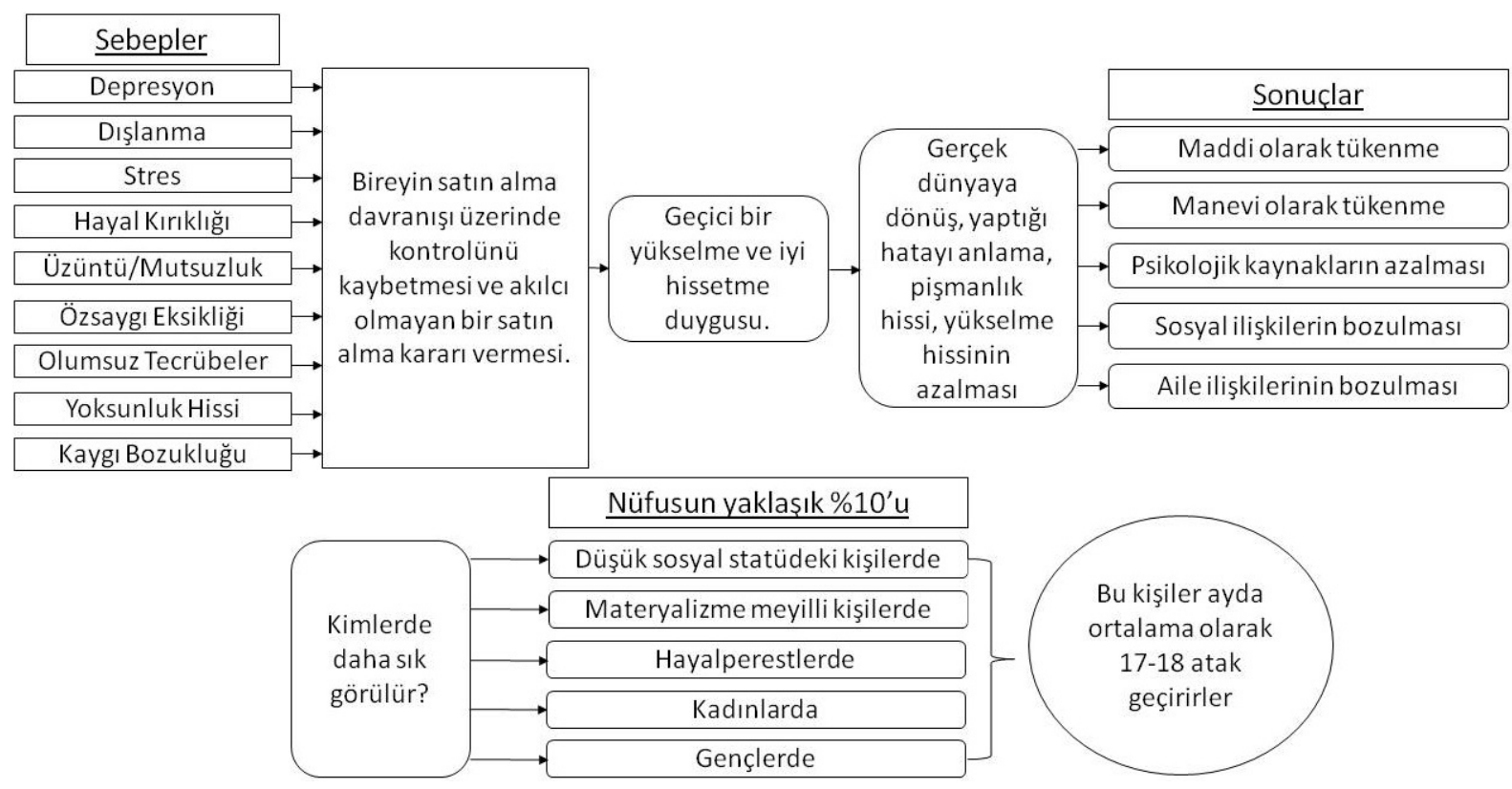

Şekil 1. Kompulsif Satın Alma Davranışının Genel Çerçevesi (1- 6, 11, 14-17)

\section{Kompulsif Satın Alma Davranışı Gösteren Tüketicilerin Özellikleri}

Hoyer ve MacInnis (18), bireylerin kompulsif olarak satın alma davranışı sergilemeleri durumunda yüksek miktarlarda ve ihtiyaçları olmayan bir takım ürünleri satın aldıklarını; ayrıca bu miktarda ürünü satın alabilecek maddi güce de sahip olamayabileceklerini ifade etmektedir.

Desarbo ve Edwards çalışmalarında kompulsif satın alma davranışını "Kompulsif olarak satın almaya sebep olan bir krizin ardından oluşan kaygı bu davranışı tetikler. Her satın almadan sonra baskı daha az hafifler ve bu sebeple birey daha sık satın almak zorunda hisseder ve bu kaygl ile hareket eder" şeklinde ifade etmişlerdir (12).

Black (19) ile McElroy vd. (2); kompulsif satın alma davranış1 bozukluğu olan bireyler; belli periyotlarda atak geçirebilirler. $\mathrm{Bu}$ ataklar genellikle bir ile yedi saat arasında bir süre zarfında etkili olur. Periyotların sıklığı kişiden kişiye değişebilir. Bazı bireylerde saat başı, bazılarında günde bir kere görülebilir. Genel itibari ile bu davranış bozukluğunu sergileyen bireyler ortalama olarak ayda 17-18 atak geçirebilmektedirler (Aktaran: 11).

Shoham ve Brencic 2003 yılında yaptıkları çalışmada KSAD ile kişilik özelliklerinin ilişkisini incelemişlerdir (20). Literatürdeki çalışmalarda Faber ve O'Guinn (21) ile Valence, d'Astous ve Fortier (7) tarafından kompulsif satın alma davranışı gösteren bireylerin materyalizme meylettikleri, hayal kurma eğiliminde oldukları; diğer taraftan yüksek seviyede depresyon, kaygı bozukluğu ve takıntı sahibi oldukları $(22,23)$; stres, hayal kırıklığı ve üzüntü ile hareket ettikleri $(1,24)$ ifade edilmektedir.
Yurchisin ve Johnson (25) 2004 yılında yaptıkları çalışmada kompulsif satın alma davranışı ile algılanan sosyal statü, materyalizm, öz saygı ve kıyafet tüketimi arasında bir ilişki olduğunu tespit etmişlerdir. Diğer taraftan kendini sembollerle tanımlama ve tamamlama süreci de kompulsif satın almanın arkasındaki itici güç olabilir savındadırlar. Araştırmacılara kıyafet ile ilintili nesnelerin (örneğin ayakkabı, aksesuar ve kozmetik ürünler) bu sürece sıklıkla dahil olmaktadır çünkü iletişim değerleri oldukça yüksektir. Kompulsif satın alma eğilimli bireylerin öz saygıları ve algıladıkları sosyal statüleri düşük fakat satın alma eğilimleri yüksektir. Muhtemelen bu sebepledir ki kompulsif satın alma eğilimi bireylerin çoğunluğu kıyafet ve ilişkili ürünleri kompulsif olarak satın almakta ve bağımlılıklarını tatmin etmeye çalışmaktadırlar $(26,27)$.

Miltenberger vd. (4) yaptıkları çalışmada alışveriş için perakende ortamına varmak üzere yola çıkan bireylerin \%50'sinin kendisini mutsuz olarak tanımladıkları ve alışverişin ardından \%42'sinin ise kendisini suçlu hissettiğini ifade etmektedir. Bu da kompulsif satın alma davranışı gösteren bireylerin olumsuz duygularla hareket ettiklerine bir işaret olarak kabul edilmektedir.

Ayrıca öz saygı eksikliği ve sosyal statü ihtiyaçları bireyleri aşırı tüketime sevk edebileceğini vurgulayan çalışmalar da bulunmaktadır (28). Diğer taraftan yapılan bazı araştırmalarda kompulsif satın alma eğiliminde olan bireylerin piyasaya yeni sürülen ürünlere herkesten önce sahip olma arzusunda olduklarını da ortaya koymaktadır. $(29,30)$.

Kompulsif satın alma davranışı gösteren kişilerde apansız, kontrol edilemeyen, takıntılı ve dürtüsel bir satın alma 
eğilimi söz konusudur; satın almadan önce ve satın alma esnasında neticeler üzerine düşünmezler (31) diyen çalışmalar olduğu gibi; kompulsif satın alma eğilimli kişilerin, alışveriş yaptıkları yerlerin ürün iadesi alıp almamaları ve bu konudaki prosedürleri ile yakından ilgilendikleri ifade eden çalışmalar da bulunmaktadir (32).

Rajagopal (33), KSAD ile satış promosyonu, perakendeci indirimleri gibi dışsal uyarıclar arasında yakın bir ilişki olduğunu belirtmektedir. Kompulsif satın alma eğilimli bireylerin bu tip uyaranların etkisine çok açık oldukları da ifade edilmektedir.

KSAD gösteren kişi; sosyal, iktisadi ve şahsi hayatı kötü yönde etkilenmesine rağmen bu davranıştan vazgeçememekte ve bu sebeple kompulsif satın alma davranışı Glatt ve Cook (34) ile Krysc tarafından alkol ve madde bağımlılığına benzetilmektedir (Aktaran: 35).

Korur ve Kimzan (36) bu tarz satın alma davranışı bozukluğuna evvela yirmili yaşların başında rastlandığını ve bunun kronik bir durum olduğunu, kadınlarda daha sık rastlandığını ve yetişkinlerde $\% 2$ ile $\% 16$ arasında bir oranda görülebildiğini belirtmektedirler. Roberts ve Pirog (37) yapmış oldukları çalışmada kadınların çekici görünmeyi erkeklerden daha fazla önemsediklerini ve KSAD gösteren kadınların kozmetik ve kıyafet için daha fazla para harcadıklarını tespit ederken, (18) ise araştırmalarında düşük öz saygı sorunu yaşayan tüketicilerin dikkat çekebilmek ve sosyal kabul görebilmek için kompulsif satın alma davranışı gösterdiklerine dikkat çekmişlerdir. Aynı şekilde Shoham ve Brencic 2003 yılında yaptıkları çalışmada cinsiyetin (çoğunlukla kadınların), yaşın (çoğunlukla gençlerin) kompulsif satın alma eğilimlerinin yüksek olduğunu belirtmektedirler (20). Roberts'ın 1998 yılında yaptığ da yine kadınların kompulsif satın alma eğilimlerinin daha yüksek olduğu ortaya konulmuştur (38). Valence vd. ise (7) düşük sosyo-ekonomik sınıflara mensup bireylerin hissettikleri baskıyı azaltabilmek için kompulsif satın alma eğiliminde olabileceklerini belirtmektedirler.

Annagür (17) Adana ilinde yapmış olduğu çalışmada, depresyondan muzdarip hastalar arasında en sık görülen dürtü kontrol bozuklukları arasında 3. sırada \%14 oranında kompulsif satın alma durumu olduğunu tespit etmiştir. Aynı çalışmada bu kişilerin büyük bölümünün kadın olduğu da belirtilmektedir. Diğer taraftan normal satın alma davranışının doğum günü ve tatil gibi bir takım özel dönemlerde kompulsif davranışa dönüşebileceği de ifade edilmektedir.

\section{Tüketicilerin Kompulsif Satın Alma Davranışı Göstermelerinin Nedenleri}

$\mathrm{Bu}$ tür davranışın gerekçesi olarak hoş olmayan hayat tecrübeleri, içsel yoksunluklar veya olumsuz duygular (8) ve bunalım, stres, kaygı bozuklukları gibi diğer ilişkili duygular $(22,23)$ literatürde ifade edilmektedir. Bu duygular, tüketicileri satın almaya yönlendirebilmekte ve böylece olumsuz duyguların yarattığ 1 stresten, rahatsızlıktan, huzursuzluktan ve yoksunluktan uzaklaştırmaktadır (23). Bu sebeple kompulsif satın alma davranışı gösteren kişilerin satın alma motivasyonu; satın alınan ürünün faydasından ziyade olumsuz duygularını hafifletmek için satın alma sürecini uyaran olarak kullanmaktır (1).

Roberts (38) Amerika’da üniversite öğrencileri üzerinde yaptığı çalışmada kompulsif satın alma eğilimi yüksek olan öğrencilerin öz saygı seviyesinin diğerlerinden daha düşük olduğunu tespit etmiştir. Buradan kompulsif satın alma eğilimli bireylerin sosyal statü ile satın alma arasında daha güçlü bir bağ olduğuna inandıkları anlaşılmaktadır.

KSAD bireylerin sahip olduğu hayal kurma becerisi araştırmacıların oldukça ilgisini çekmiştir. "Birey; hayal kurarak olumsuz duygulardan kaçınabilir ve kendisine bir sosyal kabullenme sağlayabilir" (1). Diğer taraftan hayal kurmak, bireyin olumsuz konulara odaklanmak yerine olumlu konulara odaklanmasına yardımcı olabilmektedir. Daha da ötesinde eğer "bireyin güvenlik ihtiyaçları karşılanmamışsa; birey materyalistik değerlere ve tutkularına vurgu yapmakta, böylece satın alma davranışını statü kazanmak için çalışan bir mekanizma haline getirmektedir" (39). Valence vd. (7) kaygının doğaçlama davranışı tetiklediğini ve kişiye baskıyı azaltmak için kontrolsüz bir cesaret vererek kompulsif satın almaya ittiğini ifade etmektedirler.

Bir diğer bakış açısına göre kompulsif satın almanın sebebi kaygı veya baskıyı azaltmaktan ziyade bireyin kişisel hedefleri de olabilmektedir (37). Genellikle " $b u$ amaçların başında diğerleri tarafindan kabul görme isteğinin cesaretlendirici bir etkisi olduğu” ifade edilmektedir (37). Buna atıfta bulunan çalışmalarda genellikle kişinin bedenen, kılık kıyafet ve moda anlayışı olarak diğer kişilere çekici gelme arzusuna atıfta bulunulmaktadır (40). Tüketici kültürünün güvende ve iyi olma halinin satın alınabileceğini söylediği yerlerde, kompulsif satın alma davranışı duygusal bir yükselme ve geçici bir iyi hissetme hali sunmaktadır (41). Bu sebeple "kompulsif satın alma davranışı makro seviyede özsaygıyı yükselten, amaca yönelik bir davranış" olarak da ele alınabilir (37).

Valence vd. kompulsif satın alma davranışını tetikleyen faktörleri iki ana grupta toplamışlardır. Bunlar:

a) Sosyo-kültürel faktörler: Materyalistik idealler üzerinde baskı kuran kültür, ticari hayat ve reklam faaliyetleri.

b) Psikolojik faktörler: Kişilik-durum etkileşimi, aile çevresi, genetik faktörler (7).

Bazı araştırmacılara göre (örn. 42) reklamlar bireyin duygularını manipüle ederek sanal olarak yaratılan rekabette başarı ihtiyacını giderebilmesi için kaygıyı arttırmakta ve böylece tüketicinin rasyonel olmayan bir alım davranışı göstermesine sebep olabilmektedir. 


\section{Kompulsif Satın Alma Davranışının Sonuçları}

Roberts ve Jones (24), KSAD gösteren bireylerin kullandıkları kredileri ödemede güçlük çekebildikleri veya hiç ödeyemedikleri, oldukça büyük maddi buhranlara düşebildiklerini ifade etmektedirler ve bunu da bireyin öz kontrol mekanizmasının zayıflığına bağlamaktadırlar. Literatürde kompulsif satın alma eğiliminin, pazarlama etiğinin de ilgi alanına girmesi gerektiğini savunan araştırmacılar bulunmaktadır. Hoyer ve MacInnis (18) "satış danışmanlarının kompulsif satın alma eğilimi yüksek olan müşterileri ne kadar çekici göründüğ̈̈ veya hediye alınıyorsa hediye verilecek kişinin bunu ne kadar beğeneceğ $i$ konusunda verdiği telkinler ile sıklıkla ikna edebildiklerini" belirtmektedirler. Roberts ve Jones (24) ise "reklamclların çoğunlukla fiyat vurgusunundan sonra en sık olarak statüye vurgu yaptıklarını" ifade etmektedir. Roberts ve Pirog'a (37) göre “kompulsif satın alma eğilimli bireyleri hedefleyen reklamcilar materyalistik arzuları yükselterek bireyin yaşadığı içsel baskıyı ürüne sahip olarak azaltabileceği algısını vurgulamaktadırlar”. Gilbert ve Jackaria ise (43) yaptıkları çalışmada kompulsif satın almayı tetiklemek için kullanılan 4 taktik tespit etmiş̧lerdir; alışveriş kuponları, fiyat indirimleri, deneme ürünleri ve bir alana bir bedava kampanyaları.

Odabaşı (44) ise KSAD gösteren tüketicilerin kendini gerçekleştirmeye çalışırlarken yaptıkları tüketim esnasında aslında kendilerini tükettiklerini belirtmektedir. Araştırmacılar pazarlama uygulayıcıları için aşağıda sayılan taktiklerin, kompulsif satın alma eğilimli bireyleri de düşünülerek sosyal sorumluluk prensipleri çerçevesinde gerçekleştirilmesini tavsiye etmektedirler:

- "Satış teşvik edici promosyonlar ve satış taktikleri uygulamaları,

- $\quad$ Pazar bölümlendirmede stratejileri,

- Ürün ambalajlarında kompulsif satın alma davranışını tetikleyici unsurlara yer verilmemesi,

- Ürünün tüketilmesi ile kaygların, depresyonun, kötü hislerin ortadan kalkacă̆ vurgusunun yapılmaması,

- Reklam çalışmalarında statü, prestij ve promosyonların vurgulanmamasl," (45).

Elbette ki bütün pazarlama uygulayıcılarının bu tavsiyeleri dikkate alacağını düşünmek mümkün değildir. Hatta bazı pazarlama uygulayıcılarının bireyin davranış, dürtü kontrol veya duygu durum bozukluğunun bireyin meselesi olduğunu, dolayısıyla tedbir alması gerekenin de birey olduğunu söylemeleri şaşırtıcı olmayacaktır. Buna rağmen, durumun farkında olmak, sorumluluğu almak veya almamak elbette ki pazarlama uygulayıcısının inisiyatifindeki bir konudur.

Nihayetinde kompulsif satın alma davranışı gösteren tüketicilerin maddi, psikolojik ve hatta sosyal kaynaklarını da bu davranışları neticesinde tükettikleri; dolayısıyla ağır bir bedel ödediklerini söylemek yerinde olacaktır. Bu sebeple kompulsif satın alma davranışı gösteren bireylerin ve bu davranışın sebeplerinin daha iyi anlaşılması ve ortaya konulması önemli bir ihtiyaç olarak karşımıza çıkmaktadır.

\section{Araştırmanın Amacı ve Önemi}

$\mathrm{Bu}$ çalışmanın amacı yıkıcı bir davranış şekli olan kompulsif satın alma davranışına dair kapsayıcı bir ölçme aracının ortaya konulmasıdır.

Kompulsif satın alma davranışının önemini vurgulamak adına, bu tip davranış sergileyen bireylerin toplumun yaklaşık \%10'una tekabül ettiğini belirtmekte de fayda vardır(11). Böylesi kalabalık bir tüketici kitlesinin, genel kabul gören satın alma davranışından uzaklaşmasının altında yatan motivasyon ve gerekçelerin ortaya konulmasının yerinde olacağı düşünülmektedir.

\section{Araştırmanın Kapsamı ve Verilerin Toplanması}

Araştırmanın ana kütlesi erişkin tüketicilerden oluştuğundan katılımcılar 18 yaşının üzerindeki bireylerden oluşmaktadır. Anket formları aracılığı ile toplanan veriler 1 Temmuz-1 Eylül 2018 tarihleri arasında geçen 2 aylık sürede hem internet üzerinden oluşturulan çevrimiçi soru formu ile hem de kağıda baskısı alınıp dağıtılan fiziksel soru formu ile toplanmıştır. Anket verileri Ankara ilinde kolayda örnekleme yolu ile toplanmıştır. Ankete katılım gönüllülük esasına göre olup, katılımcıların çalışmanın her aşamasında araştırmadan çekilme hakları vardır.

\section{Araştırmanın Yöntemi}

Araştırmada Faber ve O’Guinn (8) ve Edwards (9) ölçeklerinin birleştirilmesiyle üretilen 20 soruluk form, 5 'li Likert yöntemiyle test edilmiştir. Soru formunun oluşturulmasında alanında uzman 3 öğretim üyesinden görüş alınmıştır. Tablo 2'de bahsi geçen 20 soruluk form görülmektedir.

Faber ve O’Guinn (8) kompulsif satın alma tespit ölçeğini kompulsif satın alma eğiliminde olan bireyleri tespit etme ve genel nüfustan ayırmak için kurgulamışlardır. Bazı araştırmacılar 7 soruluk klinik tespit ölçeğini kendi çalışmalarında kullanmışlardır. $\mathrm{Bu}$ ölçeğe getirilen temel eleştiri ise ölçeğin kompulsif satın alma ile ilgili olarak sınırlı ve kısıtlı bir alanda açıklama getirebilmesidir $(41,46)$. Edwards ise (9) Faber ve O’Guinn'in (8) geliştirdiği ölçeğin ekstrem vakalar için uygun olduğunu ifade ederek 13 soruluk kendi ölçeğini geliştirmiştir.

$\mathrm{Bu}$ formda birden fazla parametre içeren sorular uzman görüşlerine istinaden hata vermemesi için tek parametre içerecek şekilde bölünmüş ve 26 maddelik yeni bir veri toplama aracı oluşturulmuştur. Ölçek bu şekliyle teste tabi tutulmuş olup güvenilirlik, açımlayıcı ve doğrulayıcı faktör analizleri yapılarak nihai hali verilmiştir.

Anket yöntemi ile elde edilen nicel veriler ise önce MS Office 
Tablo 2. Kompulsif satın alma davranışının ölçülmesi

\begin{tabular}{|c|c|c|c|c|c|c|}
\hline No & İfadeler & 1 & 2 & 3 & 4 & 5 \\
\hline 1 & Ay sonu geldiğinde param artmışsa, bunu harcamak zorunda olduğumu hissederim. & & & & & \\
\hline 2 & Etrafımdaki insanlar paramı nasıl harcadığımı bilselerdi dehşete düşerlerdi. & & & & & \\
\hline 3 & Ödeyemeyeceğimi bildiğim halde satın aldığım şeyler oldu. & & & & & \\
\hline 4 & Ödeyemeyeceğimi bildiğim halde kredi kartımdan alışveriş yaptım. & & & & & \\
\hline 5 & Kendimi daha iyi hissetmek için kendime bir şeyler aldım. & & & & & \\
\hline 6 & Alışverişe gitmediğim günlerde kaygıllı veya asabi hissederim. & & & & & \\
\hline 7 & Kredi kartlarım için sadece minimum ödemelerimi yapabiliyorum. & & & & & \\
\hline 8 & Param veya zamanım olmasa bile para harcamak ve alışveriş yapmak için tahrik olmuş hissediyorum. & & & & & \\
\hline 9 & Bazen çıldırmış gibi satın alırım. & & & & & \\
\hline 10 & Alışveriş çılgınlığına kapıldığımda kendimi yükselmiş hissederim. & & & & & \\
\hline 11 & Hiçbir şeye ihtiyacım olmamasına rağmen bir şeyler aldığım olur. & & & & & \\
\hline 12 & Sinirli, depresif veya mutsuz olduğum dönemlerde alışveriş çılgınlığına kapılırım. & & & & & \\
\hline 13 & İhtiyacım olmayan ve kullanmayacağım şeyler aldığım olur. & & & & & \\
\hline 14 & Bazen kendimi alışveriş yapmak zorunda hissederim. & & & & & \\
\hline 15 & Alışveriş yapmaktan pek az veya hiç keyif alamıyorum. & & & & & \\
\hline 16 & Alışverişe gitmekten nefret ederim. & & & & & \\
\hline 17 & Harcama alışkanlıklarımla ilgili endişelenmeme rağmen hala alışverişe gidip para harcıyorum. & & & & & \\
\hline 18 & Paramın yetmeyeceğini bildiğim halde bir şeyler alırım. & & & & & \\
\hline 19 & Alışveriş çılgınlığına kapıldığımda kendimi kaygılı hissederim. & & & & & \\
\hline \multirow[t]{2}{*}{20} & Alışveriş çılgınlığına kapıldıktan sonra suçlu veya utanmış hissederim. & & & & & \\
\hline & 1) Kesinlikle katılıyorum, 2) Katılıyorum, 3) Kararsızım, 4) Katılmıyorum, 5) Kesinlikle katılmıyorum & & & & & \\
\hline
\end{tabular}

İlk 7 soru: Faber ve O'Quinn (8); Son 13 soru: Edwards (9).

Excel programı üzerinde tasnif edilmiş, kontrol sorularına uygun cevap vermeyen anket formları kapsam dışı bırakılmıştır. Daha sonra bu veriler IBM SPSS Statistics 22 paket programına aktarılmış; güvenilirlik ve faktör analizlerine tabi tutulmuşlardır. Doğrulayıcı faktör analizi için ise AMOS paket programından istifade edilmiştir. Katılımcıların demografik bilgilerine dair bilgiler de frekans analizine tabi tutularak ayrıca paylaşılmıştır.

Tablo 3. Demografik verilere dair özet tablo

\begin{tabular}{|l|l|l|l|}
\hline \multicolumn{2}{|l|}{ Katılımcıların Demografik Özellikleri } & Medeni Durum \\
\hline Cinsiyet & 415 & Evli & 496 \\
\hline Erkek & 361 & Bekar & 280 \\
\hline Kadın & & Gelir Durumu & \\
\hline Yaş & 119 & 1603 TL veya daha az & 62 \\
\hline 18-28 Yaş Arasında & 428 & $1604-2800$ TL arasında & 85 \\
\hline 29-39 Yaş Arasında & 80 & $2801-3800$ TL arasında & 135 \\
\hline $40-50$ Yaş Arasında & 59 & $3801-4800$ TL arasında & 123 \\
\hline $51-61$ Yaş Arasında & 90 & $4801-5800$ TL arasında & 97 \\
\hline 62 Yaş ve Üzerinde & & $5801-6800$ TL arasında & 69 \\
\hline Eğitim Durumu & 61 & $6801-7800$ TL arasında & 77 \\
\hline Lise & 94 & $7801-8800$ TL arasında & 50 \\
\hline Ön Lisans & 525 & $8801-9800$ TL arasında & 21 \\
\hline Lisans & 96 & 9801 TL veya daha yüksek & 57 \\
\hline Yüksek Lisans & & & \\
\hline
\end{tabular}

Toplam 776 kişi

\section{Bulgular}

Elde edilen anket formlarından kullanılamayacak durumda olanlar elenmiş olup geri 776 geçerli soru formu ile analizler gerçekleştirilmiştir.

Sonuç itibari ile geçerli soru formlarına verilen cevaplara istinaden demografik değişkenlere dair genel durum Tablo 3'te görüldüğü şekildedir:

Elde edilen verilerin analizi ile oluşturulan Döndürülmüş Bileşen Matrisi tablosu üzerinden birden fazla bileşene yük veren bileşenlerin irdelenmesinden sonra ölçeğin boyutları aşağıdaki şekilde ortaya çıkmıştır. Hair vd. (47), faktör yükünün anlamlı olabilmesi için faktör yükü değerinin 0,5 veya daha yüksek olması gerektiğini ifade etmektedirler. Dolayısı boyutların oluşturulması ve faktör eksiltilmesi işlemi de buna göre yapılmıştır. Silinen bir faktörün ardından durum Tablo 4'teki gibi olmuştur.

Bilindiği üzere Kaiser-Meyer-Olkin değeri 1'e ne kadar yakın olursa verilerin faktör analizine uygunluğu o nispette yüksek çıkacaktır. Kaiser-Meyer-Olkin değerinin 0,6' dan düşük çıkması yetersiz bir faktörlenme imkanına, 0,5 'ten düşük çıkması ise faktörlenebilme imkanının olmayışına işaret etmektedir (48). Bu veri seti için KMO değeri 0,908 çıkmış olup bu değer yeterlidir. Bartlett's Test of Sphericity Sig. değeri ise 0,10 'dan düşük olup KMO ile aynı şekilde faktör analizinde ilgili verilerin uygun olabileceğini göstermektedir. 
Tablo 4. Kompulsif satın alma davranışı soru seti için faktör analizi tablosu

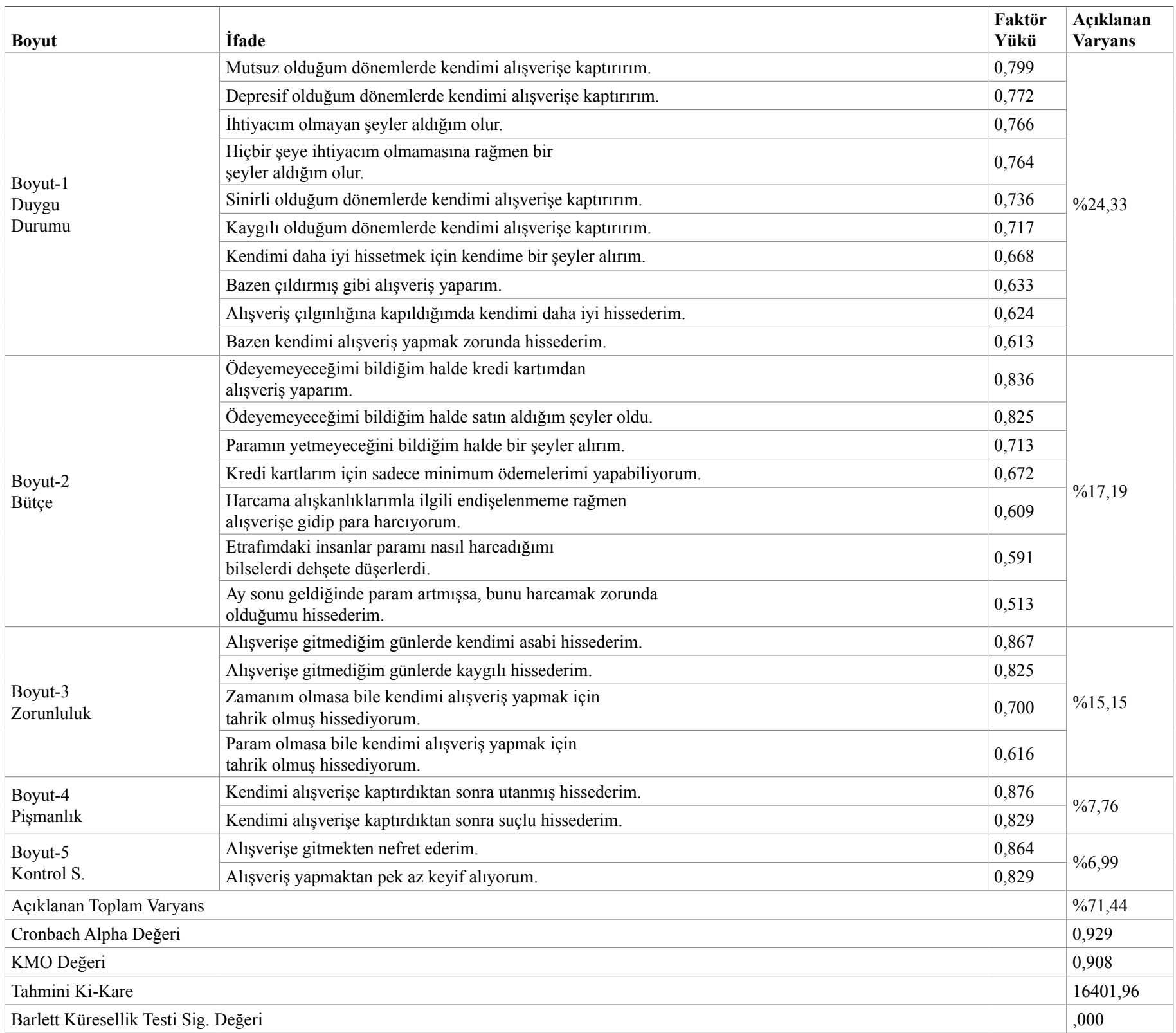

Analiz neticesinde 5 tane bileşenin Eigenvalue değeri 1'in üzerinde çıkmıştır. Buna istinaden kompulsif satın alma davranışı 25 maddeden oluşan 5 boyutlu bir yapıya sahiptir denilebilir. Faktör yükleri 0,513 ile 0,876 arasında değişmekte ve bu 25 maddenin açıklayabildiği varyans oranı ise \%71,44 olarak ortaya çıkmaktadır. Son tahlilde çalışmada kompulsiflik ile ilgili parametreleri ölçmek için kullanılan ölçeğin boyutları tabloda belirtildiği şekilde oluşmuştur.

Silinen bir soru maddesi aşağıda verilmiştir:

- Kendimi başka insanlarla kıyasladığımda, ihtiyacım olmayan şeyleri daha fazla satın aldığımı düşünüyorum.

Yapısal Eşitlik Modeli ile Doğrulayıcı Faktör Analizleri

$\mathrm{Bu}$ bölümde yapısal eşitlik modellerinden faydalanılarak uygulanan doğrulayıcı faktör analizleri aracılığı ile KSAD ve durumsal faktörlere dair kullanılan soru setlerinin yap1 geçerlilikleri test edilmektedir. Aşağıda, bu analizlerde dikkate alınacak parametrelere dair bilgiler verilmiştir.

CMIN/DF ( $\chi 2$ / df) değeri, için Wheaton vd. (49), yaklaşık olarak 5 civarındaki değerlerin kabul edilebilir olduğunu ifade ederken, Bryne (50) ise 3 ve üzerindeki değerlerin kabul edilmemesi gerektiğini ileri sürmektedir. Dolayısıyla literatürde konu ile alakalı farklı görüşlerin varlığından bahsetmek mümkündür. Marsh ve Hocevar (51) ise değerin 2 ile 5 arasında yer almasının genel olarak kabul edilebilir bir durum olduğunu ifade etmektedirler.

RMSEA değeri, popülasyonun hata tahminini tespit etmede kullanılan bir araçtır. Genel itibari ile 0,05 ile 0,08 arasındaki değerlerin kabul edilebilir bir uyuma işaret ettiği söylenmektedir (52). 


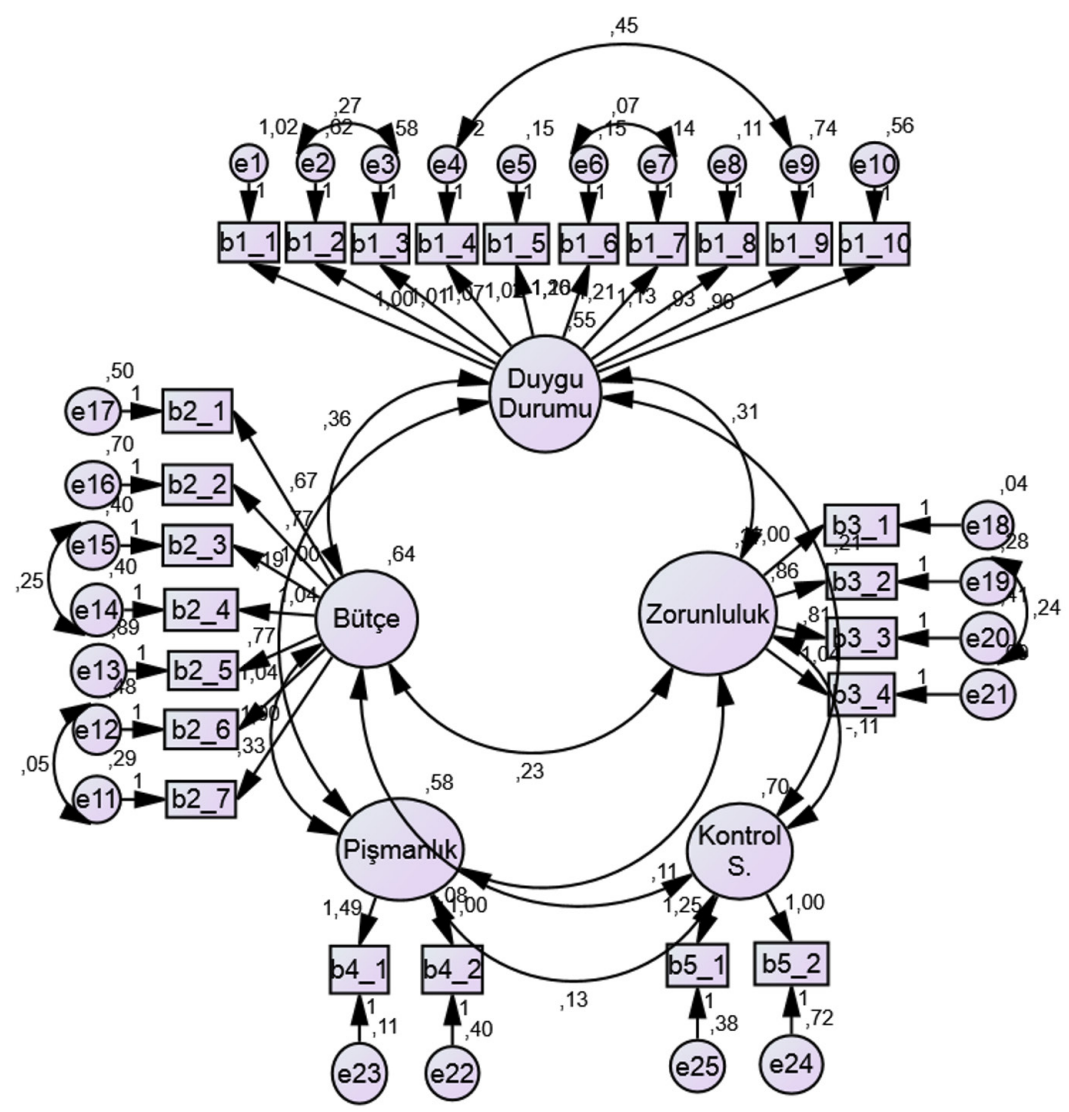

Şekil 2. KSAD için doğrulayıcı faktör analizi

$$
\text { RMSEA }=\left[\frac{\left(\chi^{2}-d f\right)}{(n-1) d f}\right]^{1 / 2}
$$

CFI değeri ise modelin tahmini kovaryans matrisi ile sifir hipotezi modelinin kovaryans matrisi arasında bir mukayese yapmaktadır. 0 ile 1 arasında değer almaktadır. Bu değer için kabul edilebilir düzey ise 0,90 'nın üzeridir (52).

$$
\mathrm{CFI}=1-\left[\frac{\max \left[\left(\chi^{2}-d f\right), 0\right]}{\max \left[\left(\chi^{2}-d f\right),\left(\chi_{\text {null }}^{2}-d f_{\text {null }}\right), 0\right]}\right]
$$

GFI değeri de CFI değeri gibi 0 ile 1 arasında değer almaktadır ve bu değer genel olarak örneklem büyüdükçe yükselme eğilimindedir. "Modelin örneklemdeki kovaryans matrisini ne oranda ölçtügünü gösterir”" (53). Geleneksel olarak kabul edilebilir düzey 0,90 olarak ele alınsa da, faktör yükleri ve örneklem büyüklüğü küçüldükçe bu düzeyin 0,95 'e kadar çekilebileceği söylenmektedir (54).

$$
\left.\mathrm{GFI}=1-\frac{\mathrm{F}[\mathrm{S}, \Sigma(\hat{\theta})]}{\mathrm{F}[\mathrm{S}, \Sigma(\theta)}\right]
$$

Tablo 5'ten de görüleceği üzere CMIN/DF değeri 2,699 çıkmış olup bu değer için genel kabul gören aralık 2 ile 5 arasıdır. CFI
Tablo 5. KSAD soru seti için doğrulayıcı faktör analizi değerleri

\begin{tabular}{|l|l|l|l|}
\hline Uyum Ölçüsü & $\begin{array}{l}\text { Ölçüm Modeli } \\
\text { Sonucu }\end{array}$ & $\begin{array}{l}\text { Kabul Edilebilir } \\
\text { Uyum Aralığı }\end{array}$ & Kaynak \\
\hline $\begin{array}{l}\text { Normalize Ki-Kare } \\
\text { (CMIN/DF) }\end{array}$ & 2,699 & $2 \leq \mathrm{CMIN/DF \leq 5}$ & $(51)$ \\
\hline $\begin{array}{l}\text { Karş1laştırmalı Uyum } \\
\text { İndeksi (CFI) }\end{array}$ & 0,912 & $0,90 \leq \mathrm{CFI}$ & $(52)$ \\
\hline $\begin{array}{l}\text { Uyum İyiliği } \\
\text { İndeksi (GFI) }\end{array}$ & 0,911 & $0,90 \leq \mathrm{GFI} \leq 0,95$ & $(54)$ \\
\hline RMSEA & 0,074 & $0,05 \leq \mathrm{RMSEA} \leq 0,08$ & $(52)$ \\
\hline
\end{tabular}

ve GFI değerleri ise 0,912 ve 0,911 çıkmış olup bu değerler için de genel kabul görmüş yaklaşım 0,90 ve üzerinde olmalarıdır. RMSEA için ise genel kabul, 0,05 ile 0,08 aralı̆ 1 olup elde edilen 0,074 değeri bu aralığın içerisindedir (Tablo 6).

Yapılan analiz neticesinde elde edilen $\mathrm{P}$ değerlerinden 1 tanesi hariç tamamı 0,05 'ten küçük olup, bu durum modelin anlamlılı̆̆ını teyit etmektedir. Kontrol soruları ile ilgili olarak uyum ihtiyacı bulunmaması sebebi ile bu durum dikkate alınmayabilir. Son tahlilde elde edilen değerlere istinaden KSAD soru setinin yapısal geçerliliğe sahip olduğunu söylemek mümkündür. 
Tablo 6. Kompulsif Satın Alma Davranışı Doğrulayıcı Faktör Analizi İstatistik Değerleri

\begin{tabular}{|l|l|l|l|l|}
\hline \multicolumn{2}{|l|}{ Boyut } & St.Hata & Krt.Dĕ̆. & P \\
\hline Duygu Durumu & Bütçe & 0,058 & 6,214 & $* * *$ \\
\hline Duygu Durumu & Zorunluluk & 0,045 & 6,84 & $* * *$ \\
\hline Duygu Durumu & Pişmanlık & 0,046 & 4,091 & $* * *$ \\
\hline Duygu Durumu & Kontrol & 0,056 & $-3,697$ & $* * *$ \\
\hline Bütçe & Zorunluluk & 0,039 & 6,041 & $* * *$ \\
\hline Bütçe & Pişmanlık & 0,057 & 5,795 & $* * *$ \\
\hline Bütçe & Kontrol & 0,052 & $-1,483$ & 0,14 \\
\hline Zorunluluk & Pişmanlık & 0,034 & 3,309 & $* * *$ \\
\hline Zorunluluk & Kontrol & 0,04 & $-2,709$ & 0,01 \\
\hline Pişmanlık & Kontrol & 0,051 & 2,459 & 0,01 \\
\hline
\end{tabular}

\section{Sonuç}

Aşağıdaki tabloda bu çalışmada elde edilen veriler ışığında yapılan faktör analizine istinaden Faber ve O'Guinn (8), Edwards (9) ve çalışmada her iki ölçeğin birleştirilmesi ile üretilen Genişletilmiş KSAD Ölçeği için elde edilen boyut sayıları ile açıklanan toplam varyans oranları ve Cronbach Alfa değerleri verilmiştir.

\begin{tabular}{|l|l|l|l|}
\hline Ölçek & $\begin{array}{l}\text { Boyut } \\
\text { Sayısı }\end{array}$ & $\begin{array}{l}\text { Açıklanan Toplam } \\
\text { Varyans }\end{array}$ & $\begin{array}{l}\text { Cronbach } \\
\text { Alfa Değeri }\end{array}$ \\
\hline Faber ve O’Guinn (8) & 2 & $64,95 \%$ & 0,830 \\
\hline Edwards (9) & 3 & $67,58 \%$ & 0,902 \\
\hline $\begin{array}{l}\text { Genişletilmiş KSAD } \\
\text { Ölçeği }\end{array}$ & 5 & $71,44 \%$ & 0,929 \\
\hline
\end{tabular}

Tablodan da anlaşılacağı üzere tarafımızca birleştirilen iki ölçekten elde edilen ölçme aracı her iki ölçeğin açıkladığı toplam varyanstan fazlasını açıklayabilmekte ve güvenilirlik değeri de aynı şekilde mevcut iki ölçeğin değerlerinden yüksek çıkmaktadır. Buradan hareketle yeni ölçme aracının kavramı daha geniş ve güvenilir bir şekilde ölçebildiği söylenebilir.

Mevcut ölçeme aracının bireyin alışveriş anındaki duygu durumu, sahip olduğu bütçeden fazlasını harcamak, alışveriş yapmaya zorunlu hissetmek, alışveriş sonrası pişmanlık ve kontrol soruları olmak üzere beş boyutu olduğu görülmektedir. Bu yapıya göre birey içinde bulunduğu duygu durumu sebebiyle kendini daha iyi hissedebilmek için bütçe sınırını aşabilecek düzeyde alışveriş yapmakta; akabinde de bu davranışından pişmanlık duymaktadır. Dolayısıyla genişletilmiş ölçeğin literatürde kavramı tanımlarken kullanılan ifadeleri de daha genel bir şekilde kapsadığı da söylenebilir.

Toplumun ciddi ve kayda değer bir kısmının muzdarip olduğu kompulsif satın alma davranışına yönelik olarak yapılan çalışmalarda konunun en geniş şekilde açıklanabilmesi için bu çalışmada üretilen ölçme aracının da kullanılabileceği, böylece literatürde sıklıkla temas edilen fakat ölçeklerin birbirinden farklı olarak göz ardı ettiği alanların da kapsam dışında kalmasının önüne geçeceği değerlendirilmektedir.

Pazarlama araştırmacıları bundan sonraki çalışmalarda Genişletilmiş Kompulsif Satın Alma Ölçeği'ni düşük fiyat garantisine karşı tutum, çevreci ürünlere yönelik tutum, reklama yönelik tutum, gösterişçi tüketim, ürüne yönelik tutum, karar verme tarzı, amaca yönelik motivasyon, suçluluk, ürün kullanım sıklığı, pişmanlık, satış teşvik tercihi, ikinci el alışveriş motivasyonu, alışveriş motivasyonu gibi ölçeklerle bir arada kullanabilecekleri gibi hediye verme, çevrimiçi alışveriş, benlik saygısı, kişilik gibi kavramlarla ele alarak alanda katkı verebileceklerdir.

\section{Hakem Değerlendirmesi: Dış Bağımsız.}

Bilgilendirilmiş Onam: Ankete katılım gönüllülük esasına göre olmuştur. Katılımcıların çalışmanın her aşamasında araştırmadan çekilme hakları vardır.

Yazar Katkıları: Fikir - AB, ZE; Tasarım - AB, ZE; Denetleme - AB, ZE; Veri Toplanması ve/ veya İşlemesi $-A B$; Analiz ve/veya Yorum - $A B$; Literatür Taraması - $A B$; Yazıyı Yazan - $A B$; Eleştirel İnceleme - AB, ZE.

Çıkar Çatışması: Yazarların herhangi bir çıkar çatışması bulunmamaktadır.

Finansal Destek: Yazarlar bu çalışma için finansal destek almadıklarını beyan etmişlerdir

Peer-review: Externally peer-reviewed.

Informed consent: Participation in the survey was on a voluntary basis. Participants have the right to withdraw from the research at any stage of the study.

Author Contributions: Concept - AB, ZE; Design - AB, ZE; Supervision - AB, ZE; Data Collection and/ or Processing - $A B$; Analysis and/or Interpretation - $A B$; Literature Search - $A B$; Writing - $A B$; Critical Reviews - AB, ZE.

Conflict of Interest: The authors do not have any conflicts of interest.

Financial Disclosure: The authors declared that this study has received no financial support.

\section{Kaynaklar}

1. O’Guinn TC, Faber RJ. Compulsive Buying: A Phenomenological Exploration. Journal of Consumer Research 1989; 16:147-157. [crossref]

2. McElroy SL, Keck PE, Pope HG, Smith MJ, Strakowski SM. Compulsive Buying: A Report of 20 Cases. Journal of Clinical Psychiatry 1994; 55: 242-248

3. Dittmar H, Drury J. Self-image is it in the bag? A qualitative comparison between "ordinary" and "excessive" consumers. Journal of Economic Psychology 2000; 21:109-142. [crossref]

4. Miltenberger RG, Redlin J, Crosby R, Stickney M, Mitchell J, Wonderlich S, et al. Direct and retrospective assessment of factors contributing to compulsive buying. J Behav Ther Exp Psychiatry 2003; 34: 1-9. [crossref]

5. Mittal B, Holbrook MB, Beatt S, Raghubir P, Woodside AG. Consumer behavior: how humans think, feel, and act in the marketplace. Cincinati: Open Mentis; 2000.

6. Ridgway NM, Kukar-Kinney M, Monroe KB. An expanded conceptualization and a new measure of compulsive buying. Journal of Consumer Research 2008; 35: 622-639. [crossref]

7. Valence G, d'Astous A, Fortier L. Compulsive Buying: Concept And Measurement. Journal of Consumer Policy 1988;11:419.

8. Faber RJ, O'Guinn TC. A clinical screener for compulsive buying. Journal of Consumer Research 1992;19:459-469. [crossref]

9. Edwards EA. Development of a new scale for measuring compulsive buying behavior. Financial Counselling and Planning 1993;4:67-84.

10. Monahan P, Black DW, Gabel J. Reliability and validity of a scale to measure change in persons with compulsive buying. Psychiatry Research 1996; 64:5967. [crossref] 
11. Tamam L, Diler SR, Özpoyraz N. Kompulsif Satın Alma: Bir Gözden Geçirme. Türk Psikiyatri Dergisi 1998; 9(3): 224-230.

12. Desarbo WS, Edwards E. Typologies of compulsive buying behavior: A constrained clusterwise regression approach. Journal of Consumer Psychology 1996; 5: 231-262. [crossref]

13. Günüç S, Keskin DA. Çevrimiçi Alışveriş Bağımlılığı: Belirtiler, Nedenler ve Etkiler. ADDICTA: The Turkish Journal On Addictions 2016;3:339-364. [crossref]

14. Dittmar H. Understanding and diagnosing compulsive buying. Handbook of addictive disorders: A practical guide to diagnosis and treatment. New York: Wiley; 2004: 411-450.

15. Jalees T. Identifying determinants of compulsive buying behavior. Market Forces 2007; 3(2): 30-51.

16. Billieux J, Rochat L, Rebetez MML, Van der Linden M. Are all facets of impulsivity related to self-reported compulsive buying behavior?. Personality and Individual Differences 2008; 44: 1432-1442. [crossref]

17. Annagür BB. Depresyon Hastalarında Dürtü Kontrol Bozuklukları Sıklığı. Yayınlanmamış Tıpta Uzmanlık Tezi. Adana; 2008.

18. Hoyer WD, MacInnis DJ. Consumer Behavior (Fourth ed.). Boston: Houghton Mifflin; 2007.

19. Black DW. Compulsive buying: A review. The Journal of Clinical Psychiatry 1996; 57:50-55.

20. Shoham A, Brencic MM. Compulsive buying behavior. The Journal of Consumer Marketing 2003; 20:127-138.

21. Faber RJ, O'Guinn TC. Expanding the view of consumer socialization: A non utilitarian mass-mediated perspective. In E. C. Hirschmann ve J. Sheth, N. (Eds.), Research in Consumer Behavior, Vol. 3. Greenwich, CT: JAI; 1987; 4977.

22. Koran LM, Faber RJ, Aboujaoude E, Large, MD, Serpe RT. Estimated Prevalence of Compulsive Buying Behavior in the United States. The American Journal of Psychiatry 2006; 163:1806-1812. [crossref]

23. Scherhorn G. The addictive trait in buying behavior. Journal of Consumer Policy 1990; 13:33-51.

24. Roberts JA, Jones E. Money attitudes, credit card use and compulsive buying among American college students. The Journal of Consumer Affairs 2001; 35:213-240. [crossref]

25. Yurchisin J, Johnson KKP. Compulsive buying behavior and its relationship to perceived social status associated with buying, materialism, self-esteem, and apparel-product involvement. Family and Consumer Sciences Research Journal 2004; 32:291-314. [crossref]

26. Lafferty HK, Dickey LE. Clothing Symbolism and the Changing Role of Nurses. Home Economics Research Journal 1980; 8:294-301. [crossref]

27. Solomon MR, Douglas SP. Diversity in Product Symbolism: The Case of Female Executive Clothing. Psychology and Marketing 1987; 4:189-212.

28. $\mathrm{Xu} \mathrm{Y}$. The influence of public self-consciousness and materialism on young consumers' compulsive buying. Young Consumers 2008; 9:37-48. [crossref]

29. d'Astous A, Jacob I. Understanding consumer reactions to premium-based promotional offers. European Journal of Marketing 2002; 36:1270-1286. [crossref]

30. Prendergast G, Tsang A, Poon D. Predicting Premium Proneness. Journal of Advertising Research 2008; 48(2): 287-296.

31. Devrani TK. Durumsal Benlik Saygısının Kompulsif Tüketim Üzerindeki Etkisi. Uluslararası Sosyal Araştırmalar ve Davranış Bilimleri Sempozyumu. 28-30 Nisan 2018. Antalya. Bildiri Özetleri Kitapçı̆̆ı; 2018: 157.

32. Hassay DN, Smith MC. Compulsive buying: An examination of the consumption motive. Psychology and Marketing 1996; 13:741-752.

33. Rajagopal D. Point-of-sales promotions and buying stimulation in retail stores. Journal of Database Marketing and Customer Strategy Management 2008; 15: 249-266. [crossref]
34. Glatt MM, Cook CH. Pathological spending as a form of psychological dependence. British Journal of Addiction 1987; 82:1257-1258.

35. Özkorumak E, Tiryaki A. Davranışsal Bağımlılık Olarak Kontrol Edilemeyen Satın Alma Davranışı. Psikiyatride Derlemeler, Olgular ve Varsayımlar 2011; 5:14-18.

36. Korur MG, Kimzan HS. Kompulsif Satın Alma Eğilimi ve Alıșveriș Sonrası Pişmanlık İliş̧isinde Kontrolsüz Kredi Kartı Kullanımının Rolü: AVM Müşterileri Üzerine Bir Araştırma. Tüketici ve Tüketim Araştırmaları Dergisi 2016; 8:43-71.

37. Roberts JA, Pirog SF. Personal goals and their role in consumer behavior: The case of compulsive buying. Journal of Marketing Theory and Practice 2004; Summer: 61-72. [crossref]

38. Roberts JA. Compulsive Buying among College Students: An Investigation of its Antedecents, Consequences, and Implications for Public Policy. Journal of Consumer Affairs 1998; 32:295-319.

39. Neuner M, Raab G, Reisch LA. Compulsive buying in maturing consumer societies: An empirical re-inquiry. Journal of Economic Psychology 2005; 26(4): 509-522. [crossref]

40. Kasser T, Ryan RM. Further examining the American dream: Differential correlates of intrinsic and extrinsic goals. Personality and Social Psychology Bulleting 1996; 22:280-287.

41. d'Astous A. An inquiry into the compulsive side of normal consumers. Journal of Consumer Policy 1990; 13:15-31.

42. McBride S. Many voices, one world: Communication in society, today and tomorrow. Unipub, New York: UNESCO; 1980.

43. Gilbert DC, Jackaria N. The efficacy of sales promotions in UK supermarkets: a consumer view. International Journal of Retail \& Distribution Management 2002; 30:315-322.

44. Odabaşı Y. Tüketim Kültürü: Yetinen Toplumdan Tüketen Topluma. 2. Bask1. İstanbul: Sistem Yayınlar1; 2006.

45. Gupta S. A Literature Review of Compulsive Buying-A Marketing Perspective. Journal of Applied Business and Economics 2013; 14:43-48.

46. Cole L, Sherrell D. Comparing Scales to Measure Compusive Buying: An exploration of their dimensionality. Journal of Advances in Consumer Research $1995 ; 22: 419-427$.

47. Hair JF, Black WC, Babin BJ, Anderson RE. Multivariate data analysis: A global perspective, (7th Ed.), NJ: Pearson; 2010: 125.

48. Field A. Discovering Statistics Using Ibm Spss Statistics, Thousand Oaks: Sage Publication; 2000: 445-446.

49. Wheaton B, Muthen B, Alwin D, Summers FG. Assessing Reliability and Stability in Panel Models. Sociological Methodology 1977; 8(1): 84-136.

50. Byrne BM. Structural equation modeling with EQS: Basic concepts, applications, and programming 2nd Edition. New Jersey: Erlbaum; 2006.

51. Marsh HW, Hocevar D. Application of confirmatory factor analysis to the study of self-concept: First- and higher-order factor models and their invariance across groups. Psychological Bulletin 1985; 97: 562-582. https://psycnet.apa. org/doi/10.1037/0033-2909.97.3.562.

52. Noudoostbeni A, Kaur K, Jenatabadi HS. A Comparison of Structural Equation Modeling Approaches with DeLone \& McLean's Model: A Case Study of Radio-Frequency Identification User Satisfaction in Malaysian University Libraries. Sustainability 2018; 10:1-16. [crossref]

53. Çapık C. Geçerlik ve güvenirlik çalışmalarında doğrulayıcı faktör analizinin kullanımı. Anadolu Hemşirelik ve Sağlık Bilimleri Dergisi 2014; 17:196-205.

54. Hooper D, Coughlan J, Mullen MR. Structural Equation Modelling: Guidelines for Determining Model Fit. The Electronic Journal of Business Research Methods 2008; 6: 53-60. http://dx.doi.org/10.21427/D7CF7R. 